\title{
Short communication
EFFECT OF CHRONIC ADMINISTRATION OF INDOMETHACIN ON HAEMATOLOGICAL PARAMETERS IN RATS
}

\author{
ADEDAPO A.A AND AIYELOTAN O. \\ Department of Veterinary Physiology and Pharmacology, University of Ibadan. Ibadan, Nigeria
}

Chronic treatment with indomethacin $(250 \mathrm{mg} / \mathrm{kg}$ and $500 \mathrm{mg} / \mathrm{kg}$ decreased packed cell volume (PCV) haemoglobin (Hb), Red

Blood Cell Count (RBC) and neutrophil values but increased the lymphocyte counts.

Keywords: Indomethacin, blood, rat

*Author for correspondence

\section{INTRODUCTION}

Indomethacin is a non-steriodal anti-inflammatory drug that was synthesized in 1963 for the treatment of rheumatoid arthritis. It is an indolemathylate derivative that has anti-inflammatory, analgesic and anti-pyretic activities (Gilman et al 1985). It contain not less than $98.5 \%$ and not more that the equivalent of $100.5 \%$ of (1(14-chlorobenzoyl)5-methoxy-indol-3-yl) acetic acid, calculated with reference to the dried substance (British Pharmacopoeia, 1998).

Indomethacin exert is effect by potently inhibiting postaglandin synthesis (Libber et al, (1986). It is used in patient that are refractory to other drugs. But despite it potency, indometacin is not continually used as an analgesic or antiphyretic because it s toxic effects have become apparent with its wider use (Schild, 1980). These adverse effects include gastric and peptic ulceration which may involve haemorrhage and acute perforation of colonic diverticuli, nausea, headache, dizziness, depression and psychosis (Gilman et al 1985). Infact acute renal failure associated with the concomittant administration of indometacin and triamterene has been reported (Clive and Stoff, 1984).

Indometacin has an intraperitoneal lethal dose of $13 \mathrm{mg} / \mathrm{kg}$ in rats (Chambers, 988). Infact, this drug has been used widely as a rodenticide in the local community and the drug is potent in causing death within 1-5 hours of administration (Makinde, 1991).

In the present study, the effect of indomethacin haematological parameters are studied in rats.

\section{MATERIALS AND METHODS The Animals}

Albino rats of the Wistar Strain were used for this experiment. The were bought from the Physiology Department of the University of Ibadan and transferred to the experimental animals house of the Department of veterinary Physiology and Pharmacology of the same University. The animals were thus housed under standard laboratory conditions and had free access to feed and clean water. The animals were fed on growers mash and stabilized for 2 weeks before the start of the experiment.

\section{Drug administration}

Indocid $^{R}$ was obtained (strides, Belgium) $25 \mathrm{mg}$ capsules with a concentration of $25 \mathrm{mg}$. Each capsule was emptied carefully into the universal bottle and was reconstituted using distilled water. The drug was orally administered in doses of $250 \mathrm{mg} / \mathrm{kg}$ and $500 \mathrm{mg} / \mathrm{kg}$ were given to the animal in groups $A$, and $B$ respectively. Group C which served as control

\section{Evaluation of Hematological Parameters}

After one-hour administration through oral route, the blood samples were collected and investigated for packed cell volume (PCV) using the microhaematocrit method, haemoglobin (HB) concentration by cyanomethaemoglobin method and red blood cell (RBC) and white blood cell (WBC) counts by the haemocytometer method.

The values of mean corpuscular volume (MCV) and mean corpuscular haemoglobin concentration (MCHC) were calculated according to Schalm et al (1975).

The effects of this drug on the haematological parameters of rats in group A and B were compared with the control group using student-t-test. Values of $P$ $<0.05$ was taken as being significant.

\section{RESULTS}

The results of this study are as presented in table 1. Treatment of rats with indomethacin at both $250 \mathrm{mg} / \mathrm{kg}$ and $500 \mathrm{mg} / \mathrm{kg}$ doses significantly decreased the PCV (P $<0.05$ and $\mathrm{P}<0.01)$, $\mathrm{Hb}$ concentration $(\mathrm{P}<0.05$ and $\mathrm{P}$ $<0.01)$, RBC $(P<0.001)$ and neutrophil levels $(P<$ 0.05 ) when compared with the untreated control (Group C). On the other hand the total leucocyte count and lymphocyte count of the animals treated with indomethacin was significantly increased when compared with the control.

\section{DISCUSSION}

There was a marked reduction in haematological parameters such as PCV, RBC, MCV, MCH and MCHC in the rats were administrated $250 \mathrm{mg} / \mathrm{kg}$ and $500 \mathrm{mg} / \mathrm{kg}$ doses of the drug. This observation may be as a result of the $25 \mathrm{mg}$ and $50 \mathrm{mg}$ are not doses. Doses are expressed in $\mathrm{mg} / \mathrm{kg}$, e.t.c. gastro intestinal tract which then lead to the loss of blood causing haemorrhagic anemia. This has thus precipitated low $\mathrm{Hb}$ and $\mathrm{RBC}$ count causing low capacity to carry oxygen with the resultant anoxia 
Table 1-

Effect of Indomethacin on Some Haematological Parameters

\begin{tabular}{|l|l|l|l|l|l|l|l|}
\hline Group & $\begin{array}{l}\text { Dose } \\
(\mathbf{m g} / \mathbf{k g})\end{array}$ & PCV (\%) & Hb g/dl & RBC (10 $\left.\mathbf{6}^{\mathbf{6}}\right)$ & WBC (x10 $\left.{ }^{3}\right)$ & Neut (\%) & $\begin{array}{l}\text { Lymph } \\
(\%)\end{array}$ \\
\hline A & 250 & $32.80 \pm 3.56$ & $9.00 \pm 1.25$ & $5.40 \pm 0.96$ & $10.4 \pm 0.48$ & $24.00 \pm 4.27$ & $72.0 \pm 5.31$ \\
\hline B & 500 & $23.00 \pm 1.87$ & $6.10 \pm 0.5$ & $3.30 \pm 0.22$ & $8.30 \pm 0.46$ & $24.00 \pm 3.54$ & $72.0 \pm 3.54$ \\
\hline C & Nil & $38.00 \pm 3.7$ & $11.7 \pm 0.67$ & $6.09 \pm 0.55$ & $4.90 \pm 0.68$ & $42.00 \pm 1.87$ & $56.8 \pm 1.79$ \\
\hline
\end{tabular}

Note: $P C V=$ Packed cell Volume; Hb= Haemoglobin; RBC = Red Blood Cell; WBC = White Blood Cell; Neut $=$ Neutrophil; Lympho = lymphocyte. ${ }^{\star P}<0.05$ ${ }^{* *} P<0.01 ; P<0.001$

cyanosis and respiratory acidosis which in turn caused the death of the rats within a short period of time (Makinde, 1991). The fact that indometacin is associated with toxic effects in a large percentage of patients that have been administered with this drug have been established (Schild, 1980). Infact it was reported that there was a $70-80 \%$ reduction by indometacin of the second pressor response to ethanol. There is thus enhancement of vasopressin activity by this drug and this can result in water retention (Libber et al, 1986). This therefore give credence to the acute renal failure associated with the concomitant use of this drug and triamterene (Clive and Stoff, 1984).

The adverse effects of these may involve haemorrhage and acute perforation of colonic diverticuli, nausea, dizziness, depression and psychosis (Gilmand, et al, 1985). It is these adverse effects that actually preclude the routine use of this drug as an analgesic or antipyretic despite its potency. The $750 \mathrm{mg} / \mathrm{kg}$ dose of the drug is surprising not as potent as it should. This may be due to error in drug administration.

As far the neutrophils there was a relative increase in this parameters dosed with $250 \mathrm{mg} / \mathrm{kg}$ and $500 \mathrm{mg} / \mathrm{kg}$ of indometacin while, animals administered with $750 \mathrm{mg} / \mathrm{kg}$ showed an apparent increase which might have been due to stress leading to demargination of neutrophils in circulation (Bush 1991). That there is increase in the TWBC following haemorrhage.

It also need to be stressed that there was lymphopenia and monocytopenia following administration of $250 \mathrm{mg} / \mathrm{kg}$ and $500 \mathrm{mg} / \mathrm{kg}$ of indomethacin to the rats while the rats administered with $750 \mathrm{mg} / \mathrm{kg}$ of the drug showed lymphocytosis and mocytosis as a result of severe stress that the animals were subjected to Gilman et al (1985) is of the opinion that indomethacin inhibits the motility of polymorphonuclear leukocytes. This may account for this observation i.e. Iymphoenia and monocytopaenia.

\section{REF'ERENCES}

British Pharmacopoeia, 1998. Ed. Vol. 1

Bush, B.M. (1991): Interpretation Of Result In Clinical Medicine. Blackwell Scinetific Publication Pp. 35-40.

Chamber, H.M. (1988): Macmillan Dictionary Of Toxicology. Macmillan Press Limited Pp. 200

Clive, D.M And Stoff, J. S. (I 984): Renal Syndromes Associted With NonSteroidal Anti Inflammatory Drugs. N. Engl. J Med. 310: 563-572.

Gilman, A.G., Goodman L.S., Rall, T. W. and Murad, F. (1985): Goodman And Gilman's The Pharmacological Basis Of Therapeutics 7th Ed. Macmillan Publishing Co. New York, Pp. 695-697.

Libber, S, Harrison, D. And Spector, D (1986): Treatment Of Nephrogenic Diabetes Insipidus With Prostaglandin Synthesis Inhibitors. J. Paediat. 36: 335.

Makinde, A.J. (1991): The Toxic Effect Of Varying Doses Of Indometacin On The Laboratory Rodents. DVM Dissertation, University Of Ibadan (Unpublished).

Schalm,O.W. Jain, N.C. And Caroll, E.J. (1975): Veterinary Haematology 3rd Ed. Lea And Febiger Philadelphia Pp. 602630.

Schild, H.O. (1980): Applied Pharmacology. 12th Ed. Churchill Living Stone. New York. Pp 290.

\section{Received: July 1999}

Accepted in final form: May 2001 